\title{
フェムト秒レーザーによる太陽電池用有機薄膜の加工
}

\author{
倉田 達也，津田 紀生，山田 譈，落合 鎮康 \\ 愛知工業大学 工学部電気学科（７４70-0392 愛知県豊田市八草町八千草1247）
}

\section{Processing of Solar Cell Organic Thin Film by Femtosecond Laser}

\author{
Tatsuya KURATA, Norio TSUDA, Jun YAMADA, and Shizuyasu OCHIAI \\ Fuculity of Engineering, Aichi Institute of Technology, 1247 Yachigusa, Yakusa-cho, Toyota-shi, Aichi 470-0392
}

(Received November 29, 2012)

\begin{abstract}
Solar cells using natural power sources continue to develop rapidly. In the future, we expect to use organic thin film solar cells instead of inorganic solar cells because $\mathrm{CO}_{2}$ emissions can be reduced during their manufacturing processes. However, the conversion efficiency of organic thin film is lower than that of inorganic solar cells, and organic thin film is also susceptible to heat. We propose secondary processing of organic thin film by high-power laser. Femtosecond laser and YAG lasers are focused on organic thin film in the XY stage to measure the processed thin film by DFM. The transmitted light at the laser's processed zone is measured to estimate the absorbance characteristics. The peak wavelength of the absorbed light of PCDTBT processed by femtosecond laser shifts to a shorter wavelength.
\end{abstract}

Key Words: Organic thin film, Laser processing, Femtosecond laser, Absorbance characteristic

\section{1.はじめに}

近年, 自然エネルギーを利用した太陽電池は急速な発 展を遂げており住宅やビル，工場の屋根に設置されてい る。また，電力の供給が難しい場所でのエネルギー源と して海洋や山岳地带の観測機器や人工衛生, 宇宙ステー ション等で幅広く用いられている. 現在使用されている 太陽電池の材料には無機物であるシリコンが主流となっ ている。これは無機太陽電池の電力変換効率が20〜24\% までに達している事やレーザー照射による熱加工が容易 であるためである。しかし, 資源に制約がある事や融点 が高いために製造時にコストがかかってしまう欠点があ る。一方, 光吸収層に有機物を用いる有機太陽電池は製 造時に発生する $\mathrm{CO}_{2}$ 排出量を抑える事が可能で, 資源の 制約も少ない. また, 大面積の基板に対して製膜する事 が可能である。ささら高い柔軟性を持つことから設置場 所の形状にとらわれることが少なく，幅広い場面での使 用が期待される。しかし，有機薄膜太陽電池は活性層に 無機材料を使用した太陽電池に比べて電力変換効率が低 ( ${ }^{1,2)}$. 現在における有機薄膜太陽電池のエネルギー変 換効率としては，7.4\%達成の報告がされるに至ってい る3)。また，製膜後の表面は損傷を受けやすく，熱に対 して非常に弱いという久点がある。よって従来の無機系 太陽電池の製造の際に用いられたレーザーによる熱加工 は不向きである。さらに製膜後の薄膜は電極部を取り付 ける等セル化の際に薄膜の加工を行う必要があるが, 従 来のレーザー加工では光エネルギーを熱エネルギーに変 換する間接加工を行っているために，熱が表面を伝わる
事で加工を施さない部分にも損傷を与えてしまうという 問題が発生する。

そこで本研究室では光電界が高く，且つパルス幅が $100 \mathrm{fs}$ であつェムト秒レーザーを用いて光化学効果を 利用した直接加工を行う事で熱による影響を抑えた有機 薄膜の加工に応用できるのではないかと考えた。そここで エネルギー依存性, 断面測定から加工の状態を, そして 透過光強度特性, 減衰率特性から加工後の材質の変化を 調査した.

本研究では製膜後の有機薄膜への加工の際にフェムト 秒レーザーを使用する有効性と, 吸収波長の異なる有機 薄膜を多層化することによって広い吸収波長域を備えた 効率的な有機太陽電池を作り出すことを目的としてい る.

\section{2. 実験装置}

有機薄膜加工にはTHALES LASER社製Alpha10のフェ ムト秒レーザー(波長 $800 \mathrm{~nm}$ ，パルス幅 $100 \mathrm{fs}$ ，最大出力 $1 \mathrm{TW}$ をを用いている。また，比較用のために波長

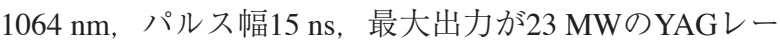
ザーを使用した。加工の際には射出口から出たレーザー 光を金コーティングした軸外し放物面鏡を使用して有効 焦点距離である $152.4 \mathrm{~mm}$ 付近に設置したX-Ystage上の有 機薄膜へと垂直に照射を行った。その様子をFig. 1に示 す。シード光だけが発射されている状態で薄膜に照射す るレーザー光の位置を定め, その後フェムト秒レーザー を発射して加工を行った。放物面鏡を使用する事でレン 


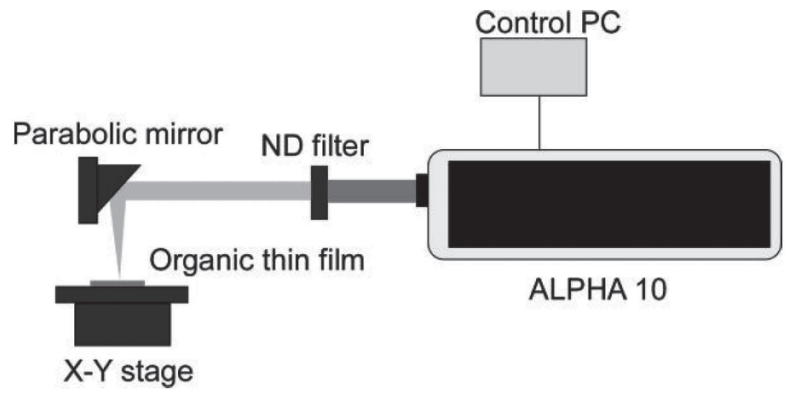

Fig. 1 Set up for femtosecond laser processing.

ズで生じる収差を防いでいる，射出口からのレーザー光 はパワーが高いためにND filterを介して減衰を行った。 YAGレーザーでも同様の方法で加工を行った，加工後 の薄膜は光学顕微鏡とエスアイアイ・ナノテクノロジー 社製走査型電子顕微鏡SPA400-DFMを使用して観測を 行った，有機薄膜試料が軟性のために非接触であるダイ ナミックフォースモード(Dynamic Force Mode: DFM)を 使用し，表面形状測定及び，断面測定を行った。また， 二次加工後の有機薄膜における材質の変化を吸収波長と いう点から調べた．Fig. 2 に実験装置の概略を示す，光 源にはハロゲンランプを使用し, 分光器で透過光の波長 依存性を測定し, 吸光度を求めた。光源からの光を両凸 レンズにより集光させて有機薄膜試料を介し, その透過 光を再び両凸レンズで集光させて光ファイバを通して分 光器へと送っている. 分光器にはOceanOptics HR4000を 使用した. 吸収波長ピーク付近である500〜 $750 \mathrm{~nm}$ の光 強度が最大になっている。

使用した試料はスピンコート法によって4000 rpmで製 膜した。有機薄膜材料にはPoly [[9-(1-loctylnonyl)-9Hcarbazole-2,7-diyl]-2,5-thiophenediyl-2,1,3-benzothiadiazole-4, 7-diyl-2, 5-thiophenediyl] (PCDTBT) とPoly [ (4,8-bis (octyloxy) Benzo (1,2-b:4,5-b') dithiophene-2,6-diyl) (2((dodecyloxy) carbonyl) thieno (3,4thiophenediyl) ] (PTB1) の二種類を使用した. Fig. 3は各製膜法を表している. スピンコート法は高速回転する基板に塗布液を落とし,

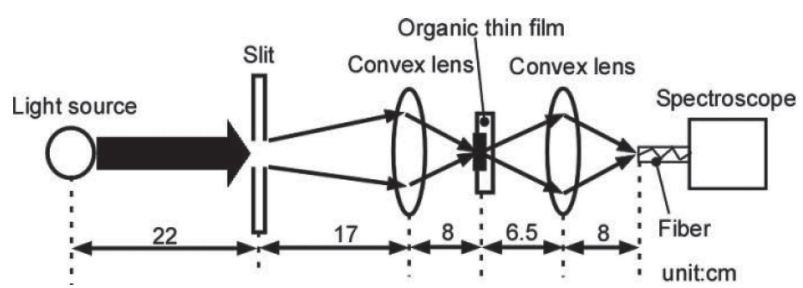

Fig. 2 Schematic diagram for measurement of transmitted light.

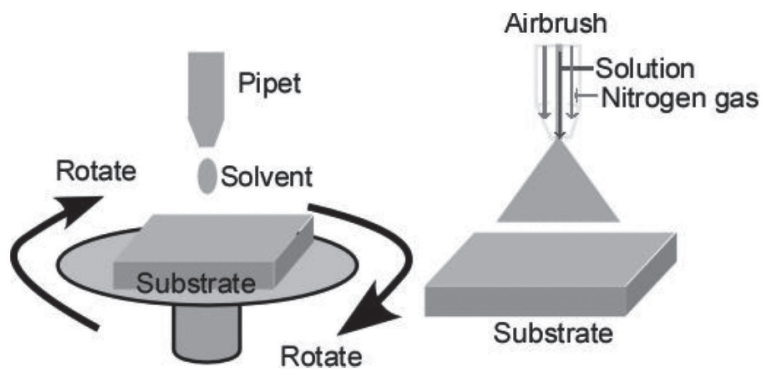

Fig. 3 Spin coating method and Spray method.
遠心力で製膜する方法である。回転数が高くなる事に よってより膜厚を均一にできる。 スプレー法では基板の 上に溶液を吹き付けて製膜する方法である。 スピンコー 卜法の様に均一な製膜はできない。また，フェムト秒 レーザーでの単発照射による深さ方向を測定するために 膜厚が厚い試料が必要であったので，スピンコート法に より $4000 \mathrm{rpm}$ で製膜したPCDTBT上にPTB7をスプレー 法で積層化した試料を作製した。

\section{3. 実験結果及び検討}

PCDTBTの薄膜をYAGレーザーで単発照射を行い, 加 工した有機薄膜の表面を光学顕微鏡で観測した様子を Fig. 4に示す.レーザーフルエンスが3.21 J/ $\mathrm{cm}^{2} の$ 場合, 加工部の直径が $170 \mu \mathrm{m}$ である。レーザー照射によって 有機薄膜は加工されているが, 加工部の周辺にも損傷が 及んでいるのが確認された。これはシリコンなどの無機 材料と異なり熱に弱い有機薄膜はナノ秒程度のパルスで は熱による損傷が起こりやすいためである。一方, フェ ムト秒レーザーで加工した様子をFig. 5に示す。レー ザーフルエンスが $26.4 \mathrm{~mJ} / \mathrm{cm}^{2}$ の場合, 加工部の直径が

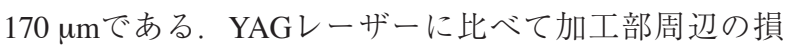
傷が抑えられているのが分かる。 また，Fig. 6, 7ではセ ル化の際の二次加工を想定して, 材料をX-Ystageで一方 向に移動させながら，それぞれのレーザーを単発照射し

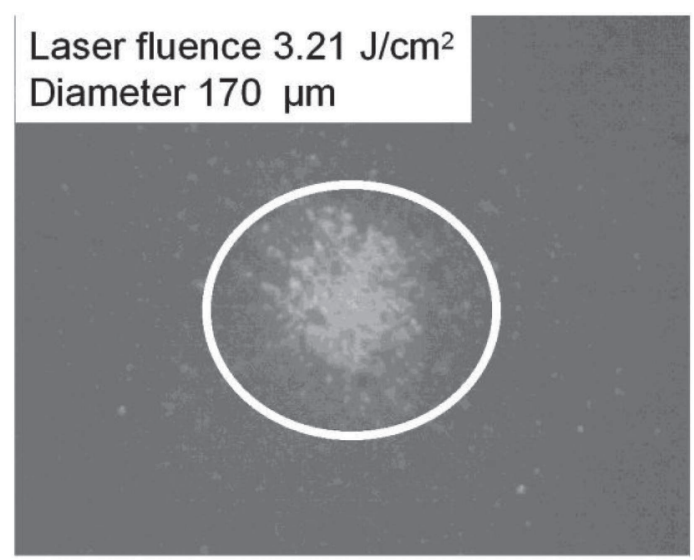

Fig. 4 Microscope image processed by single shot YAG laser.

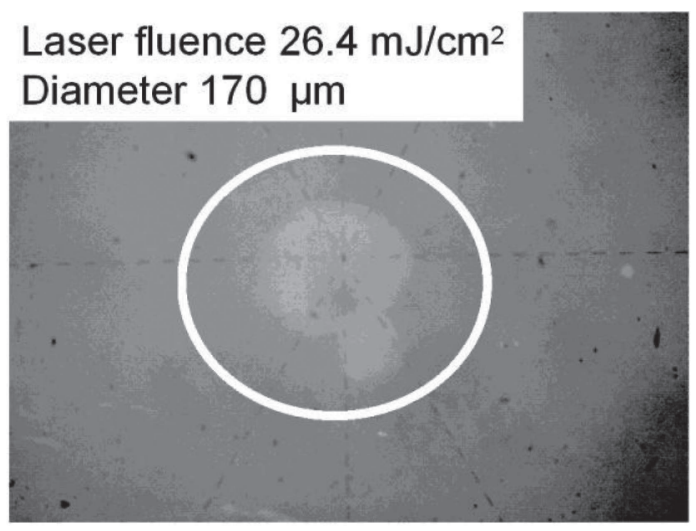

Fig. 5 Microscope image processed by single shot femtosecond laser. 


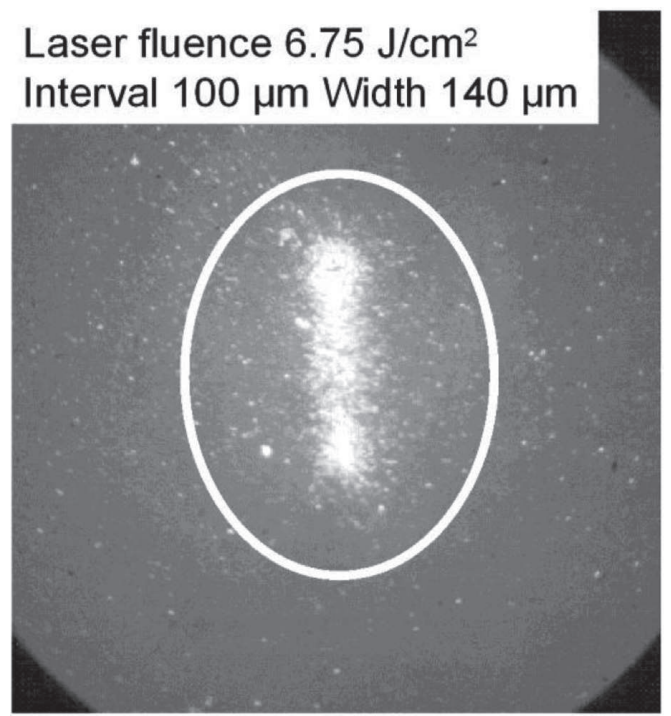

Fig. 6 Microscope image continuously processed by YAG laser.

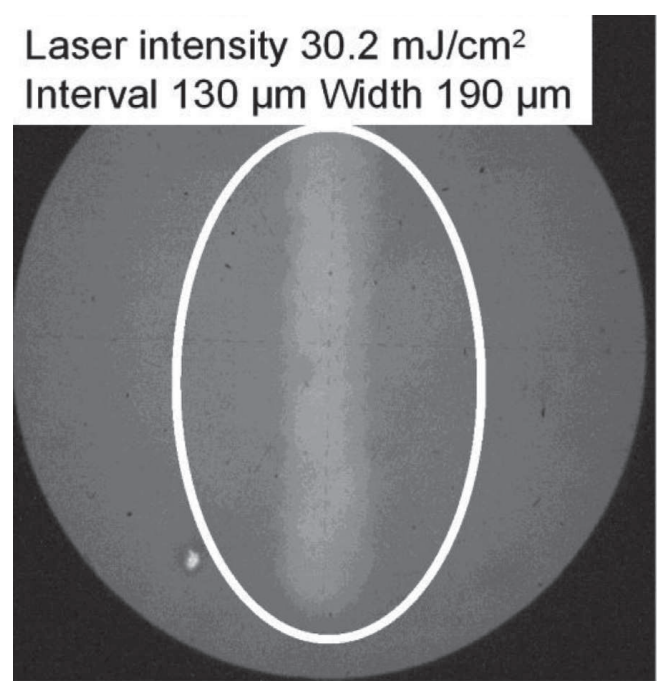

Fig. 7 Microscope image continuously processed by femtosecond laser.

て線としてつなげたものである。穴加工と同様に線状加 工でもYAGレーザーでは加工部周辺の損傷が確認され たが，フェムト秒レーザーでは周辺部への損傷が抑えら れている.

次にレーザーフルエンスに対する加工穴の面積を測定 した結果をFig. 8に示す。加工穴の面積がレーザーフル エンスに依存することが確認された。これはレーザーの 光強度がガウス分布をしているためにエネルギーの増加 に伴ってしきい值を超える領域が増加するためだと考え られる.YAGレーザーのアブレーションしきい值は $1.3 \mathrm{~J} / \mathrm{cm}^{2}$ でフェムト秒レーザでは $13 \mathrm{~mJ} / \mathrm{cm}^{2}$ となった。ま た，YAGレーザーとフェムト秒レーザーを使用した場 合を比較するとフェムト秒レーザーはパルス幅が短いの で低いレーザーフルエンスで加工が可能である事が確認 された。同様にPTB1の試料を用いて単発照射を行うと YAGレーザーではレーザーフルエンスが $3.52 \mathrm{~J} / \mathrm{cm}^{2}$ の場 合, 加工部の直径 $164 \mu \mathrm{m}$ であった。 またフェムト秒 レーザーでは2 $28.2 \mathrm{~mJ} / \mathrm{cm}^{2}$ で加工部の直径は $140 \mu \mathrm{m}$ であっ た.
Femtosecond laser fluence $\left(\mathrm{mJ} / \mathrm{cm}^{2}\right)$

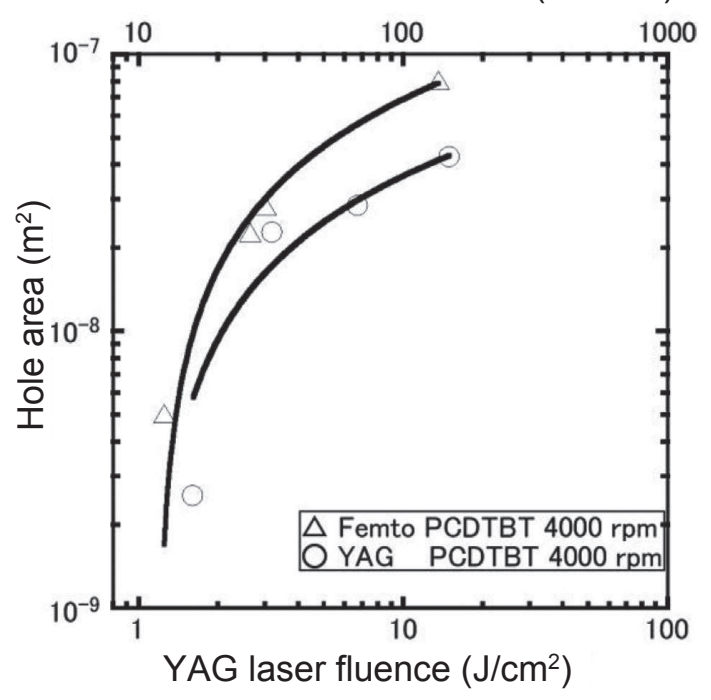

Fig. 8 Hole area processed by YAG laser or femtosecond laser as a function of laser intensity.

加工後の表面はPCDTBTと同様にYAGレーザーでは加 工部周辺に損傷が，フェムト秒レーザーではその損傷が 抑えられている事が確認できた。これらの結果から試料 の材質によるレーザーでの加工の違いはみられなかった。

次にレーザー照射後のPCDTBT表面形状測定の結果を 示す. Fig. 9はYAGレーザーを使用時の, Fig. 10はフェ ムト秒レーザー使用時のレーザー照射部と未照射部の境 界の部分を，原子間力顕微鏡を用いて測定したものであ る. Fig. 9，10からはどちらのレーザーを使用しても境 界部分は同じ加工状態であるように思われる。そこで Fig. 9，10に示したcross section部分の断面を測定し，境 界部を拡大した結果をFig. 11，12に示す。YAGレーザー 照射後の加工部周辺の薄膜表面は断面の形状から粗く なっているのが確認された。これはYAGレーザーのパ ルス幅が $15 \mathrm{~ns}$ であることからレーザーの光エネルギー が熱エネルギーに変換され，照射の際に熱が周辺部に伝 わったものと考えられる。一方，フェムト秒レーザー照 射後の加工部周辺の薄膜表面への損傷が少ないことが確

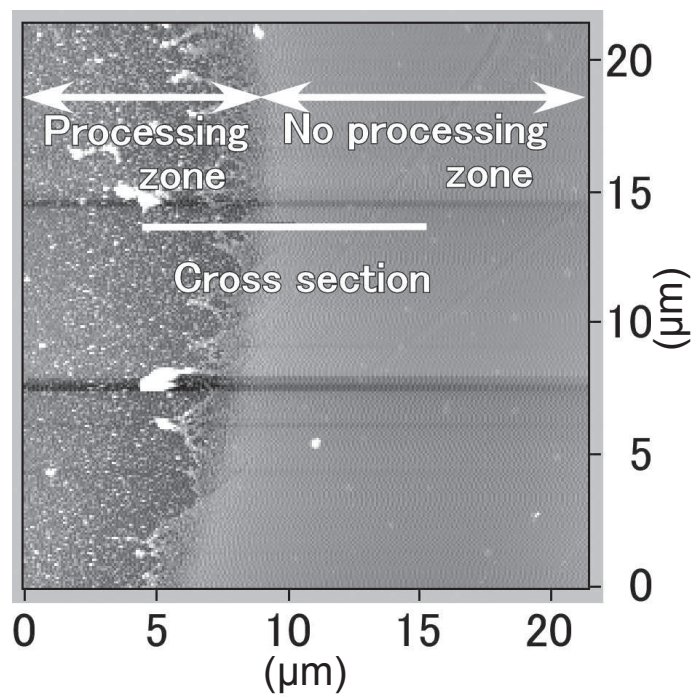

Fig. 9 Atomic force microscope image processed by YAG laser processing. 


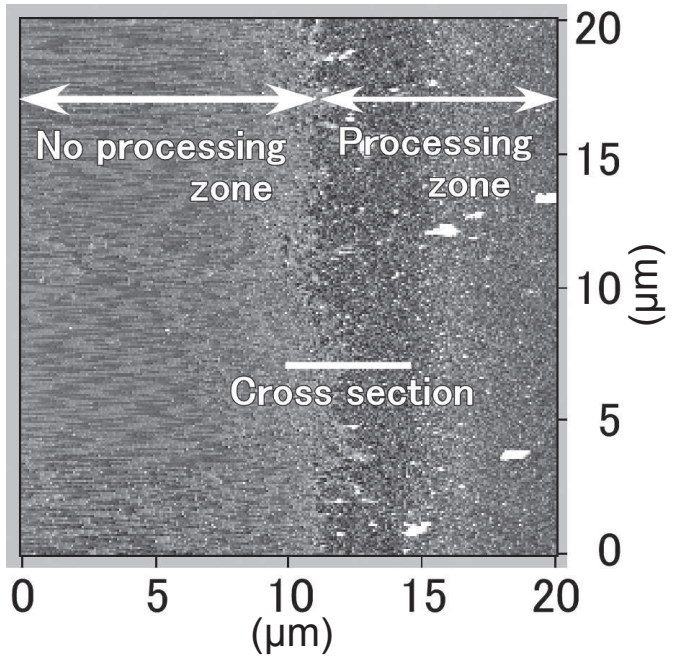

Fig. 10 Atomic force microscope image processed by femtosecond laser processing.

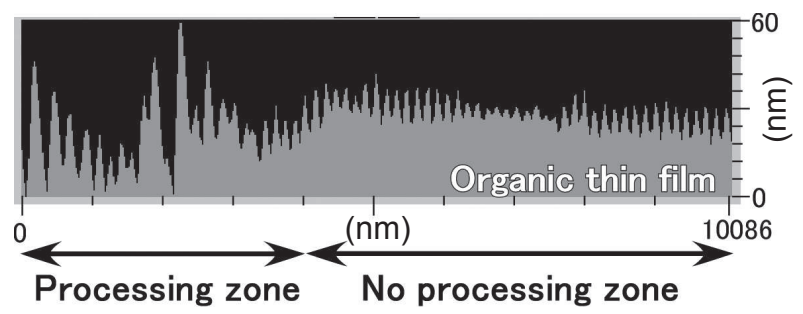

Fig. 11 Cross section image processed by YAG laser.

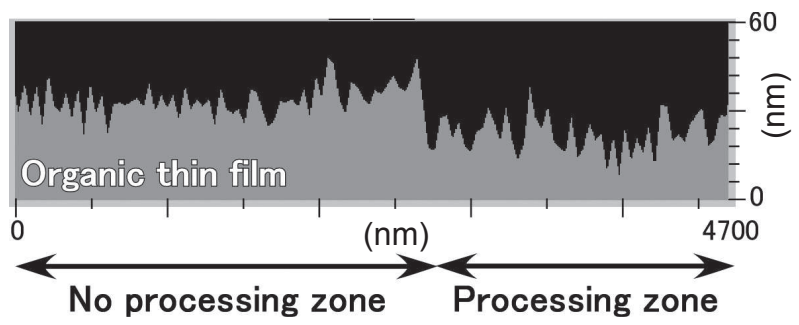

Fig. 12 Cross section image processed by femtosecond laser.

認された。フエムト秒レーザーでは周囲への熱伝導の時 間よりも遥かに短い時間に照射部の励起および温度上昇 が終わってしまうからであると考えられる。また, 積層 化した有機薄膜を使用して深さ方向の測定を行った。 フェムト秒レーザーを $0.28 \mathrm{~J} / \mathrm{cm}^{2}$ で単発照射すると, 加 工断面図から深さ方向に最大 $500 \mathrm{~nm}$ 程加工ができてい ることが確認された。

次にレーザー照射後の有機薄膜試料の材質変化の有無 を調べるために透過光測定を行い，そこから吸光度を算 出した結果を示す. Fig. 13, 14はガラス, レーザー未加 工部, 加工部中心, 加工部周辺での透過光をカウントし たものである、YAGレーザーでは加工が進み有機薄膜 の厚さが薄くなると透過光がより減衰し，吸収よりもむ しろ散乱により減衰が起きていると思われる。しかし フェムト秒レーザーを使用した場合, 有機薄膜の厚さが 薄いほど透過光強度が強く, 薄膜での吸収による減衰が 起きている，有機溶媒はそれぞれで固有の吸収波長域が あり, PCDTBTでは560 nm付近で最も吸収が起こる。こ
れよりフェムト秒レーザーを照射した場合，材質に変化 が起こることが考えられる.

未加工部の透過光のカウント数を基準として吸光度を 算出し，薄膜の加工の位置によって並べたものを Fig. 15, 16に示す.

照射前に比べて吸収波長のピークの位置に変化はない が，半值幅が変化することが確認された。これはレー ザー照射による加工表面の粗さによって光の散乱が生じ たために受光部に入る透過光が減少したためではないか と考えられる。

フェムト秒レーザーを照射した場合，YAGレーザー で見られた半值幅の変化は確認されなかったが，吸収波 長のピークの位置が短波長側へとシフトした ${ }^{4,5)}$. フェ ムト秒レーザーでは光電界が強いために分子と分子の結 合を直接断ち切る事ができ，有機薄膜の高分子が低分子 化し，材質が変化したためと考えられる，PTB1では YAGレーザー，フェムト秒レーザーを照射した場合で も吸収波長のピークの変化が認められなかった。

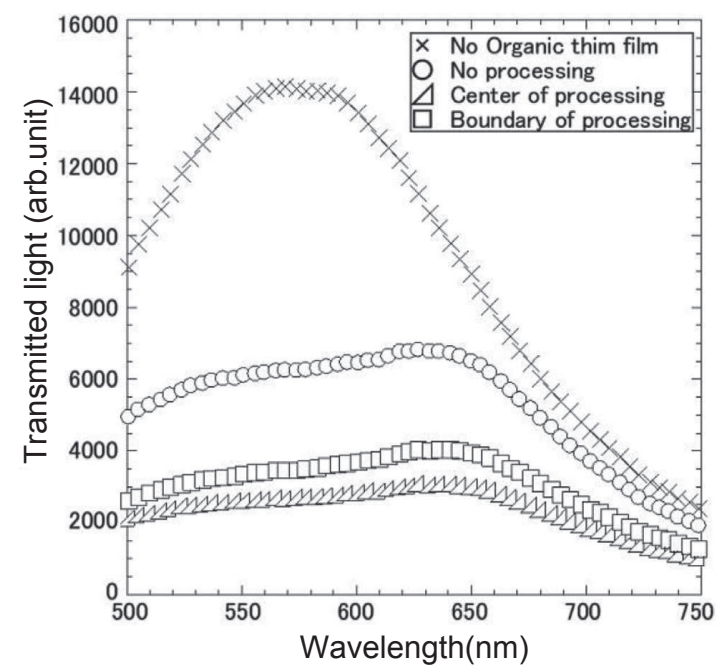

Fig. 13 Transmitted light through thin film processed by YAG laser.

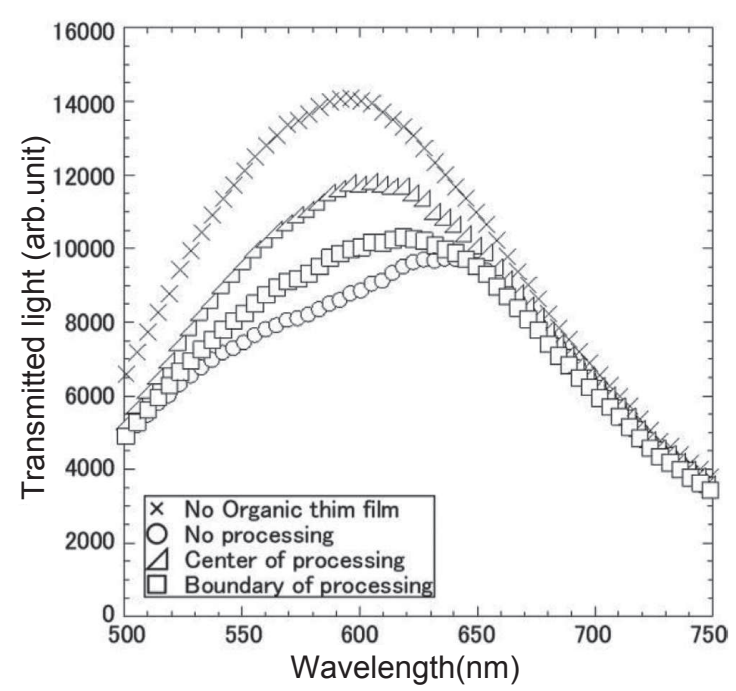

Fig. 14 Transmitted light through thin film processed by femtosecond laser. 


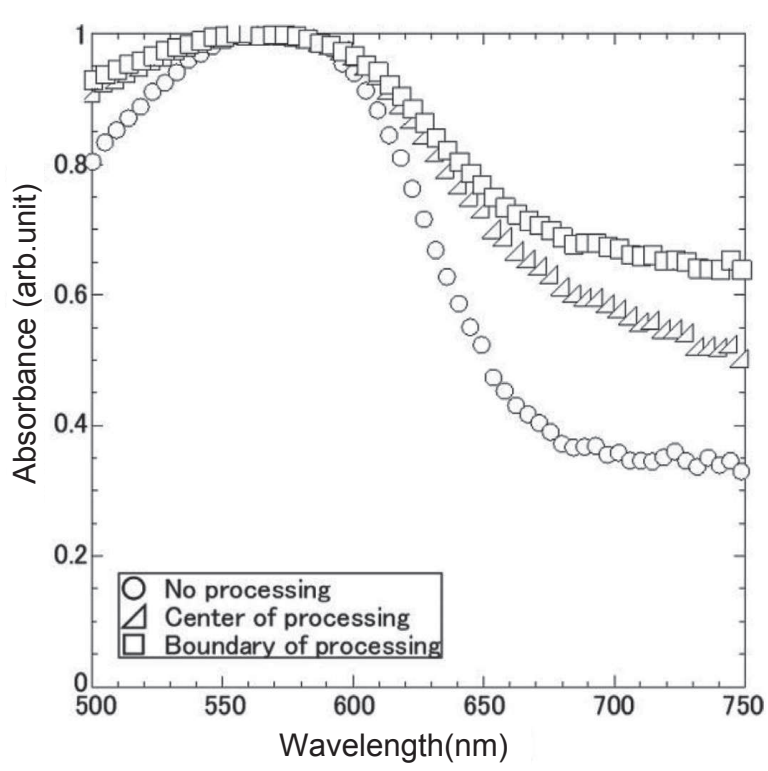

Fig. 15 Measured absorbance of thin film processed by YAG laser.

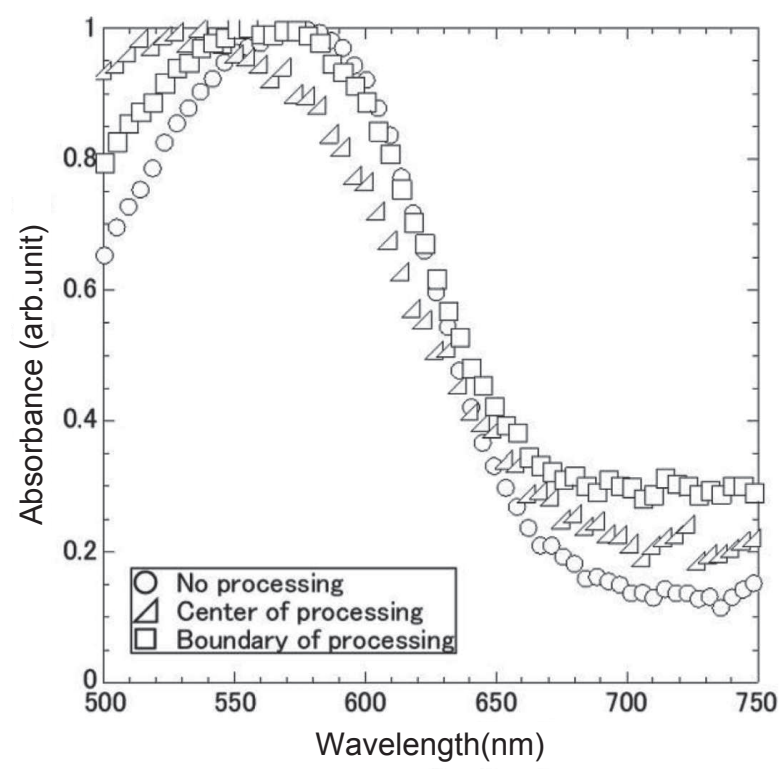

Fig. 16 Measured absorbance of thin film processed by femtosecond laser.
4. まとめ

有機薄膜太陽電池の加工に対してレーザーを用いて行 うことを考え，有機薄膜にフェムト秒レーザーとYAG レーザーを集光照射し，加工特性について検討した。 YAGレーザーを照射した場合には加工部周辺にも損傷 を与えてしまう事が確認された。しかし，フェムト秒 レーザーを用いた場合には加工部周辺に与える損傷を抑 えて加工できる事が光学顕微鏡による表面観測及び DFMによる加工断面の測定から分かった。これはフェ ムト秒レーザーでは周囲への熱伝導の時間よりも遥かに 短い時間に照射部の励起および温度上昇が終わってしま うからであると考えられる。

吸光度特性の結果からPCDTBTの薄膜にYAGレーザー を照射した場合には吸光度のピーク波長はほとんど変化 しなかった。しかし，フェムト秒レーザーを照射した際 に吸収波長のピークが短波長側へとシフトする事が確認 された。 有機薄膜には固有の吸収波長を持つために加工 によって材質の変化が生じたのではないかと考えられ る。PTB1ではYAGレーザー, フェムト秒レーザーを照 射した場合でも変化が確認されなかった。

\section{謝 辞}

本研究は文部科学省私立大学戦略的研究基盤形成プロ ジェクト－S1001033及び私立大学研究設備補助金の援 助を受けて行われた。

\section{参考文献}

1) J. Xue, et al.: Adv. Mater 17 (2005) 66.

2) 吉田 隆：薄膜太陽電池の開発最前線 (NTS, 東京都, 2005).

3) Y. Liang, Z. Xu, J. Xia, S. Ting. Tsai, Y. Wu, G. Li, C. Ray, and L. Yu: Adv. Mater. 22 (2010) 1.

4) J. Ru, K. Kojima, T. Mizutani, and S. Ochiai: Jpn. J. Appl. Phys. 49 (2010) 01AE07-1.

5) J. Ru, J. Ramajothi, T. Mizutani, K. Kojima, and S. Ochiai: Trans. IEEE Japan 130-A (2010) 181. 